\title{
Energy Value of the Shrew, Sorex ornatus
}

Wartość energetyczna ciała ryjówki, Sorex ornatu.s

\author{
James R. NEWMAN ${ }^{1}$
}

\begin{abstract}
Newman J. R., 1977: Energy value of the shrew, Sorex ornatus, Acta theriol., 22, 19: 274-275.

The mean caloric content of the North American insectivore, Sorex ornatus, was found to be similar to European insectivores. Small seasonal variation was observed. No sexual difference in energy content was noted.
\end{abstract}

[Dept. Zool., Univ. Calif., Davis, California, 95161, USA]

Most caloric values estimated for small mammals have been for rodeits (Brisbin, 1970; Fleharty et al., 1973: K a u $\mathrm{m}$ a $\mathrm{n}$ et al., 19'5) and European insectivores ( $\mathrm{G}$ ó e cki, 1965; M y r cha, 1969). This note reports the energy value for a North American insectivore, Sorx ornatus.

I measured the caloric content of 21 ornate shrews captured in the salt marshes of San Pablo Bay, California. Animals were collected frim three periods of the year: fall (August, September, October), winer (December), and spring (April) during 1969 and 1970. Shrews were killıd, sexed, wet-weighed and freeze-dried for nine days to a constant dry weight. Since freeze-dried weight approximated the 1 to 2 gram sample size, complete and intact animals were burned in a Gallenkamp adiabaic bomb calorimeter following the procedures of the Animal Nutrition Iaboratory of the University of California, Davis. The burning of the while shrews eliminates any error resulting from grinding and pelletizing. Several animals from the spring, heavier than the recommended size, were cut in half and burned separately.

The mean annual caloric value for $S$. ornatus was $4.82 \pm .03$ (S. E.) kcl/ gm dry weight $(\mathrm{n}=21)$. The mean annual dry weight was $1.50 \pm .07$ (S. 3.) grams. The caloric value of the ornate shrew was not significantly afferted by sex. The overall annual mean for males $(n=10)$ was $4.83 \pm 06$ (S. E.) $\mathrm{kcal} / \mathrm{km}$ dry weight and for females $(\mathrm{n}=8) 4.80 \pm .03$ (S. E.) $\mathrm{kcal} / \mathrm{mm}$ dry weight. No difference was noted in the caloric content of a pregnent female with four embryos (4.75 kcal/gm dry weight). The caloric content of $S$. ornatus showed small seasonal variation. The overall seasonal means were $4.76 \pm .03$ (S. E.) kcal/gm dry weight for fall $(\mathrm{n}=8), 4.80 \pm .10$ (S. 3.) $\mathrm{kcal} / \mathrm{gm}$ dry weight for winter $(\mathrm{n}=6)$, and $4.88 \pm .05$ (S. E.) kcal/gm d.y weight for spring $(n=6)$. The water content of the ornate shrew ranged from $65 \%$ total body weight in the spring to $71 \%$ total body weight in

${ }^{1}$ Present Address: Huxley College of Environmental Studies, Western Vashington State College, Bellingham, Washington 98225 USA. 
the fall. As a result of these seasonal variations in caloric value and water content the caloric value of shrews on a live weight basis varied considerably. It ranged from $1.33 \mathrm{kcal} / \mathrm{gm}$ live weight in the fall to $1.71 \mathrm{kcal} /$ gm live weight in the spring.

The caloric content on a dry weight basis for Sorex ornatus (range 4.69 to $5.22 \mathrm{kcal} / \mathrm{gm}$ ) is similar to the estimated caloric contents for European insectivores (range 4.80 to $5.19 \mathrm{kcal} / \mathrm{gm}$ for $S$. araneus, range 4.88 to 5.16 $\mathrm{kcal} / \mathrm{gm}$ for $S$. minutus, and range 4.44 to $5.21 \mathrm{kcal} / \mathrm{gm}$ for Neomys fodiens; M y c ha, 1969) and for rodents (average ranges for sixteen rodents 4.77 to $5.39 \mathrm{kcal} / \mathrm{gm} ; \mathrm{K}$ a u f $\mathrm{m}$ a $\mathrm{n}$ et al., 1975). Live weight caloric values for shrews and rodents are also similar (G ó r e c ki, 1965; M y rcha, 1969; Fleharty et al., 1973; Ka ufman et al., 1975). Golle y (1969-70) found no significant differences in caloric content of cotton rats because of sex or reproductive state. Seasonal differences in caloric content of small mammals have been found in other insectivores (M y r ha, 1969) and in rodents (Golley, 1969-70; K a u man et al., 1975).

I am grateful to R. J. Brown and G. L. Stevens for assistance in collecting the shrews and to Dr. R. L. Rudd who provided counsel and guidance. I would like to thank Dr. M. H. Hildebrand for use of his freeze-drying apparatus and the Animal Nutrition Laboratory, University of California, Davis, for the use of their facilities. This article is based in part on my $\mathrm{Ph} . \mathrm{D}$. thesis and was supported in part by NSF grants (NSFGB-6392 and NSFGB-15916).

\section{REFERENCES}

B ris bin I. L., 1970: A determination of live-weight caloric conversion factors for laboratory mice. Ecology, 51: 541-544. F l e harty E. D., $\mathrm{Kr}$ a u s e M. E. \& S t innett D. P., 1973: Body composition, energy content, and lipid cycles of four species of rodents. J. Mammal., 54: 426-438. G oll e y F. B., 1969-70: Caloric value of cotton rats (Sigmodon hispidus (Say and Ord)). 143-147. [In: »Energy Flow Through Small Mammal Populations«, K. Petrusewicz and L. Ryszkowski, Eds.]. Polish Scientific Publishers, 1-298. Warszawa. G ó r e ck i A., 1965: Energy values of body in small mammals. Acta theriol., 10: 333-352. K a uf man D. W., K a uf$\mathrm{man}$ G. A. \& W e iner J. G., 1975: Energy equivalents for sixteen species of xeric rodents. J. Mammal., 56: 946-949. M y r ch a A., 1969: Seasonal changes in caloric value, body water and fat in some shrews. Acta theriol., 16: 211-227.

Accepted, November 2, 1976. 